\title{
Work Motivation in Temporary Organizations: Establishing Theoretical Corpus
}

\author{
Ravikiran Dwivedula ${ }^{1, *}$, Christophe Bredillet ${ }^{2} \&$ Ralf Müller ${ }^{3}$ \\ ${ }^{1}$ Department of Business Administration-Faculty of Arts, Brandon University, Canada \\ ${ }^{2}$ School of Business Administration, Université du Québec à Trois-Rivières, Canada \\ ${ }^{3}$ Department of Leadership and Organizational Behavior, BI Norwegian Business School, Norway \\ *Correspondence: Brandon University, 270, 18th Street, Brandon, MB R7A 6A9, Canada. Tel: 1-514-402-3422. \\ E-mail: DwivedulaR@BrandonU.Ca
}

Received: May 26, 2018

Accepted: July 11, $2018 \quad$ Online Published: July 23, 2018

doi: $10.5430 / \operatorname{mos} . v 5 \mathrm{n} 3 \mathrm{p} 29$

URL: https://doi.org/10.5430/mos.v5n3p29

\begin{abstract}
The purpose of this article is to organize this literature, which will facilitate a systematic investigation of work motivation in temporary organizations. First, we highlight the limitations of current theoretical lenses of work motivation specific to temporary organizations. Second, we synthesize three major theories- Event-Systems (E-S) theory, Socio-Technical Systems (STS) Perspective/Job Design, and Actor-Network Theory (ANT) to establish the theoretical corpus for our proposed model of work motivation. Our model conceptualizes project work characteristics as an 'Event' capable of producing an 'event outcome' which is work motivation. This is explained using E-S and STS/ Job Design theories. Propositions are introduced. The moderation effect is explained using ANT. Third, we present the academic contribution of our proposed model.
\end{abstract}

Keywords: work motivation, project work, event-system theory, socio-technical systems, actor-network theory, job design, temporary organization

\section{Introduction}

\subsection{Research Question}

Research in the area of project-human resource management has generated considerable interest in the recent past (c.f. Keegan, Huemann, \& Turner, 2012; Cohen, Ornoy, \& Baruch, 2013; Müller \& Turner, 2010) including understanding work motivation (Sieler, Lent, Pinkowska, Pinazza, 2012). However, the literature may have fallen short in considering the role of context to explain work motivation. The theories of work motivation applied to explain work motivation in temporary organizations have been based on investigations in permanent organizations; characterized by enduring or stable features of individuals, teams, and organization. Temporary Organizations (as its nature been extensively studied, c.f. Mattias, Lundin, Söderholm, 2014), are characterized by a dynamic work environment (Turner, Huemann, and Keegan, 2008; Turner \& Müller, 2003). Such a context has significant implications for managing human resources (Clegg, \& Courpasson, 2004) and therefore work motivation of the actors working in temporary organizations. Thus, investigating a variable such as work motivation in the context of temporary organization will have to take into account the complexity of the (temporary organization) context and its dynamism. This necessitates considering theoretical lenses from outside temporary organizations/project management literature from disciplines such as industrial/organizational psychology to extend the theoretical foundations of work motivation in temporary organizations (c.f. Kanfer, 2009; Kanfer, Chen, \& Pritchard, 2008). Thus, we investigate the following research question:

How can a structured literature review grounded in multiple theoretical lenses advance future research on work motivation in temporary organizations?

\subsection{Research Gap}

My point of departure for this study was to synthesize the literature on work motivation in the field of project 
management. We considered Web of Science, a comprehensive database covering all the major journals related to project management and its allied fields to conduct this initial literature review. We used the key words "motivation" and "project management" to conduct the search and obtained 145 peer reviewed articles to perform content analysis. The key word co-occurrence relation from these articles reveals that a majority of the studies on work motivation are investigated from the project manager's point of view. This is evident from the key word manager. In here, topics such as leadership style, communication, managing project team, and decision making have been explored. The second cluster comprises of the key word challenge which pertains research design employed in project management studies. Therefore, key words such as stakeholder, methodology, firm, and practical implications are found in this cluster. A third cluster- student pertains to researching project management in a university setting, by setting up experimental designs. Thus we see some of the terms such as course, program, and experience. The fourth cluster-software engineering comprises of studies specific to the industry-management of information technology/information systems projects and therefore has key words such as task and requirement. Finally, a minor cluster five-Strategy pertains to management of projects. Hence we find key words such as goals, clients, and sustainability.

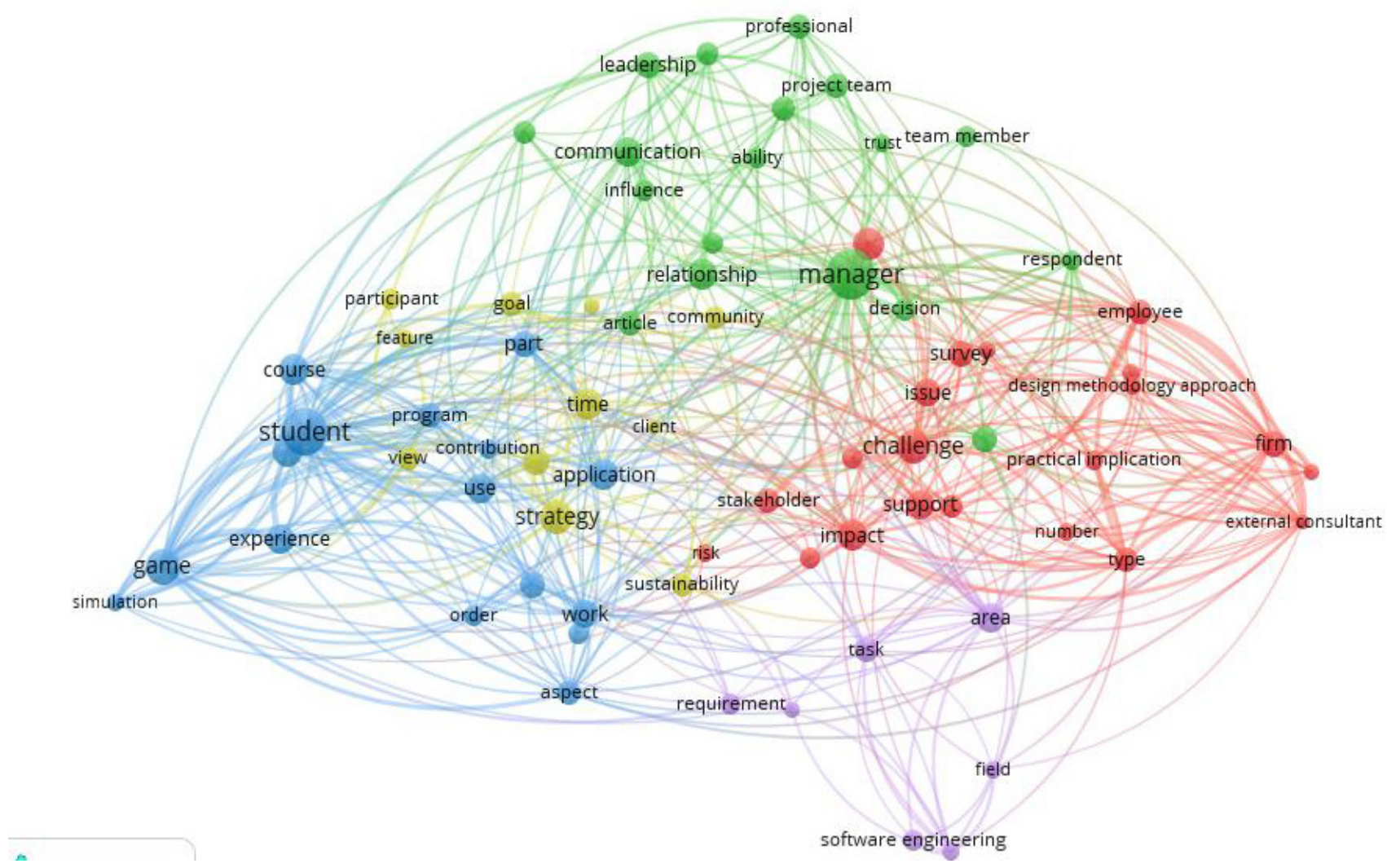

Figure 1. Content Analysis of Literature: Motivation Studies in Project Management

Thus, it is evident from this analysis that although there have been studies on work motivation in project management, investigations based on a robust theoretical lens may have been lacking. Therefore, this calls for a need to invoke an emerging theoretical perspective such as event-systems theory to better understand work motivation.

\subsection{Organization of the Paper}

The current paper is organized as follows. First, we present the theoretical ground, discussing the major theories used in this study- Event System Theory, Socio-Technical Perspective/ Job Design theories, and Actor-Network Theory. Second, we introduce the propositions. Third, we present the major contributions of the study to both work motivation, and temporary organizations/ project management literature. This will be followed by conclusion 


\section{Theoretical Ground}

\subsection{Overview of Event-System Theory}

The Event System theory proposed by Morgeson, Mitchell, \& Liu (2015) is grounded in the open systems theory which successfully explains how events bring about changes such as changes in the behavior (of individuals), (organization) features such as structures or norms, or create subsequent events. An assumption of this theory is that an Event is construed to be 'system' of interacting entities. This understanding of what is an 'event' also serves as a precursor to the use of socio-technical system perspective. STS proposed that an organization or any social unit (such as a large group, task groupings etc) comprises of technical structures, and work roles-two systems which are a part of a larger inclusive system (Mumford, 2006, Emery, 1978; Cherns, 1976). The technical system includes technology and the related work structure. The social system comprises of individuals being grouped into social units, and coordination between these social units. Motivation is explained as an outcome of interaction between these social and technical units. A more specific conceptualization of work motivation based in STS is provided by the job design perspective. Motivating job characteristics which are an outcome between the actor (social) and the artefact (technical) units lead to work motivation.

The event-systems theory is also useful to conceptualize temporary organizations as events. Events as temporary organizations are discrete, discontinuous happening which are a digression from the routine or stable features of the organizational environment, driving strategic change initiatives, characterized by uncertainty and have a start and end date (Johns, 2006). Finally, Events are created as a result of interaction between 'entities' or from the action of a single entity. An Entity is the basic unit of analysis and can include people (subordinates, managers etc), social units (such as teams, large groups), and environments (regions, industries, etc; cited in Morgeson, Mitchell, and Liu, 2015 building on the works of Katz, \& Kahn, 1978). Entities are stable and routine, and when they interact lead to the discontinuous and non-routine event(s).

\subsection{Motivating Nature of Project Work: The Job Design Perspective}

In the previous section, we have established the concept of temporary organizations, and Project Work as 'events'. In this section, we will elaborate and focus on the motivating nature of project work and work motivation.

Over the years, several approaches have been pursued to investigate the constructs, antecedents, and outcomes of work motivation. Although there are several frameworks suggested to explain work motivation (c.f. Latham \& Pinder, 2005), the common dimensions seem to be (i). needs, drives, and traits (that are largely biological in nature), (ii). Context (that explains constructs such as job design and person-context fit to define work motivation), and (iii). Cognition (that explain motivation as an outcome of one's (behavioral) self- regulation in relation to the context and needs/ drives. For the purpose of this paper, we will restrict the discussion to the Context-Work design theories of work motivation to derive an operational definition of work motivation, and use Pinder's definition of work motivation (1988) as a point of departure- set of energetic forces that originate both from within as well as beyond the individual's being to initiate work-related behavior (Pinder, 1998). It induces actions in the employees, and explains the direction, intensity, and duration of their behavior.

Empirical research on work design has predominantly focused on Hackman and Oldham's Job Characteristic Model (1976) that proposed five job dimensions which motivated employees- skill variety, task identity, task significance, feedback, and autonomy. The same model to measure work motivation has been used in the subsequent studies in this period (Champoux, 1980). The job characteristic model has also drawn considerably from the socio-technical system studies (Cherns, 1976) that identifies autonomy at work, challenging nature of work, opportunities for learning on the job, and feedback from work as being constituents of work motivation. Apart from the job characteristics model, other theoretical lenses that have shaped research on work motivation from the job design perspective are Tavistock Studies (Trist \& Bamforth, 1951, Cherns, 1976), Scientific management research (Taylor, 1911), Herzberg et al Two factor theory of motivation (1959), Job enrichment perspective (Paul, Robertson, \& Herzberg, 1969), Rockeach's Value expression \& self identification (1973), Redundancy of Functions (Emery \& Emery, 1976), Demand Control Model (Karasek, 1979), Distal Motivation (Kanfer, 1990), and Morgeson and Humphrey's Extended Job Characteristic Model (2006).

\subsubsection{Work Motivation in Temporary Organization}

There has been growing interest on what motivates project workers recently. Various theoretical lenses such as Socio-Technical Perspective, scientific management (c.f. Rose \& Manley, 2008), job characteristic model (c.f. Mahoney, \& Lederer, 2006; Bjorklund, 2010), and intrinsic motivation perspective have been used to explain work motivation in temporary organizations. 
We reiterate here that the focus of our paper is to propose a theoretical framework to explain work motivation in temporary organizations. Therefore, specific characteristics of motivating nature of work are not discussed elaborately. However, we will summarize the major literature from temporary organizations that describe specific job characteristics which are motivating in the context of temporary organizations.

Table 1. Mapping of Literature to Theories on Work Motivation in Temporary Organizations

Basis for work motivation item

Work Motivation in Temporary

Organizations

\begin{tabular}{l} 
Theory \\
\hline Scientific Management (Taylor, \\
1911) \\
Tavistock Studies on \\
Socio-Technical Systems \\
Approach (Trist \& Bamforth, \\
1951); Cherns (1976) \\
Walker \& Guest (1952) \\
Two Factor theory (Herzberg, \\
Mausner \& Snyderman, 1959) \\
Job Enrichment (Paul, \\
Robertson, \& Herzberg, 1969; \\
Paul \& Robertson, 1970) \\
Job Characteristic Model \\
(Hackman, \& lalwler, 1971; \\
Hackman \& Oldham, 1976) \\
Redundancy of Functions \\
(Emery, 1976)
\end{tabular}

Financial incentives related to productivity (performance)

Principles of Socio-Technical Systems-autonomy, task identity, meaningfulness of task, feedback on performance

Employees required to undertake a variety of tasks through job rotation and job enlargement

Nature of work itself as an intrinsic motivator for the employee; job security as an extrinsic motivator

Challenging nature of work, autonomy at work, and providing a sense of achievement to the employee

Five core job characteristics proposed- skill variety, task identity, task significance, autonomy, and feedback

Creation of groups within the organization is a precursor to project-based organizations

Freedom to participate in decisions that affect their work activity, A chance to learn on the job and go on learning, optimal variety, mutual support, and respect of their work colleagues, a socially meaningful task

Demand Control Mode (Karasek, 1979)

Resource Allocation Perspective (Naylor, Pritchard, \& Ilgen, 1980);

Distal Motivation (Kanfer, 1990)

Job Performance (Campbell, 1990)

Extension to Job Characteristic Model (Morgeson \& Humphrey, 2006)
Challenging nature of work, autonomy at work

Personal growth, and job enrichment (autonomy at work)

Communication and collegiality among group members are specific task behaviors that lead to performance

Autonomy at work

Five core job dimensions

Task Variety, Skill Variety, feedback from others, feedback from work itself, access to work specific information, informal communication
Seiler, Lent, Pinkowska, \& Pinazza (2012)

Parker, Wall, \& Cordery (2001); Mahoney \& Lederer (2006); Schmid \& Adams (2008)

Procaccino, Verner, \& Lorenzet (2006); Badir, Buchel, \& Tucci (2012); Schmid \& Adams (2008), Polesie (2013)

Mahoney, \& Lederer (2006); Kluger, \& DeNisi (1996); Ling, \& Loo (2014)

Sieler, Lent, Pinkowska, \& Pinazza (2011); Welch, Welch, \& Tahvanainen (2008)

Sieler, Lent, Pinkowska, \& Pinazza (2011), Leung, Chan, \& Dongyu (2011)

Li, Bingham, \& Umphress (2007)

Kluger, \& DeNisi (1996); Nesheim, \& Smith (2015)

Turner, \& Lloyd-Walker (2008); Bjorklund (2010); Schmid \& Adams (2008), Ling, \& Loo (2014) 


\subsubsection{Work Characteristics and Work Motivation: Event and Event Outcome}

Based on the above discussions on the event-systems theory, and the job design perspective (drawn from the socio-technical school of work motivation), we integrate these theories to conceptualize work motivation in case of temporary organizations.

From the temporary organizations literature, we know that a project actor 'interacts' with various project artefacts such as project documents, tools, techniques, and methods to produce meaningful outcomes on the project. Based on the discussion from Event-Systems theory, we propose that the Project Actor and the Project Artefacts are two Entities that interact to create an Event which is the nature of work of work.

The job design perspective (drawn from the socio-technical school of thought) defines this nature of work in terms of task identity, task variety, task significance, autonomy at work, personal growth, informal communication between the project actors, and access to work related information.

However, Event-Systems theory and the job design perspective may be inadequate to explain the 'strength' of this relationship between work characteristics and work motivation. Event-Systems theory identifies 'event-criticality', 'event-novelty', and 'event-disruption' as the three moderating variables that affect the relation between event and the event outcome (in this case, work characteristics and work motivation). Given the dynamic nature of temporary organizations where the work characteristics are constantly changing, and actors being engaged with each other differently during the course of its (TO) life, we use Actor-Network Theory to provide an operational definition for the three moderating variables.

\subsection{Actor Network Theory (ANT) to Explain the Strength of Relationship between Work Characteristics and Work Motivation}

Recent research in temporary organizations has focused on understanding the social relationships between the project actors, and the relation between these social relationships, structure, and processes that occur in temporary organizations. Call to reconsider the theoretical lenses to conceptualize temporary organizations is also gaining momentum (Levitt, 2012; Söderlund, 2004; Lundin, \& Söderholm, 1995; Packendorff, 1995). The justification to use ANT has also been provided by Jean-Louis, Langley, and Rouleau (2007) who have applied this framework to explain strategizing in pluralistic contexts (where the objectives of the social unit are is divergent, power is diffused, and the social unit is characterized by knowledge-based work; all of which conform to the conventional characteristics of temporary organizations). ANT then allows any entity to be described in terms of actors and network that support it. Furthermore, ANT also explains how the human actor is defined by her relationships-the thoughts, feelings, identity of any human actor is the result of her interaction with the non-human actors (artefacts; Latour, 2005; Sage, Dainty, \& Brookes, 2011). This conceptualization of the Actor-Network is drawn from the works of Latour (1996) who has clarified the ontology of Actor-Networks. As opposed to the notion where an actor-network is a conceptualization of social relationships between the actors, he posits that the network does not confine itself to the human actors alone but to the relationship between the actor and the non-human actor. This conceptualization is particularly relevant to the present study where we investigate the motivating nature of project work (read non human actor) interacting with the project worker (the human actor) to produce work motivation (of the human actor).

Before we set out to describe our view of ANT as one of the theoretical lenses to explain work motivation in temporary organizations, we draw on some fundamental concepts related to ANT which will indicate how the interaction between the actors and the environment leads to certain outcomes. we use the seminal work by Clegg, and Haugaard (2009) as a point of departure. They cite the concept of 'agencement' (Callon, 1986) to describe the workings of the actors and the network and 'agency'- the medium through which things are accomplished. ANT rejects the notion of 'man' being the master of technology. Instead, they bring to the fore the concept of 'agencement' which is generating outcomes through the association between 'man' and the 'network'. Thus, rather than the outcomes being predominantly affected by the human consciousness, the outcomes are achieved by the interaction between man, and the technology. This is more consistent with modern organizations, and more so for temporary organizations where technology works with men rather than for men. Thus, the actor and the network can be construed as a 'system' (c.f. Strathern, 1991).

Thus, our conceptualization of ANT clearly delineates the actor and the artefact. Furthermore, ANT assumes 'System' like characteristics which has sub-systems interacting with each other (see Latour, 1986; Callon, 1986). It is the interaction between these sub-systems which leads to the outcomes rather than human consciousness. The outcomes that ANT produces in this case is the moderating role of the 'strength' of relation between the Event and the Event-Outcome; Concepts of ANT, particularly those related to the interaction of the actor and the artefact are used 
to provide an operational definition to the moderating variables.

We now extend this conceptualization to temporary organizations.

Actor-Network Theory (ANT, Callon, 1986,1987; Latour, 2005) has been used as a theoretical lense to explain various topics in project management practice (Sage et al, 2011), and theory (Alderman, \& Ivory, 2011; Cicmil, \& Hodgson, 2006). ANT recognizes that a temporary organization will comprise of actors who interact with each other and create a network (Assudani \& Kloppenborg, 2010). Using the network perspective also overcomes the limitations of distance between the actors, and the actors and the non-actors when explaining the nature of relationships. In a permanent organization, the actors working in close proximity or in a hierarchical relationships tend of influence each other more than actors spatially dispersed by a hierarchy. Therefore, explaining the outcomes of the interaction between the actors or between the actors and the non-actors would have to account for these spatial contingencies.

On the other hand, conceptualize the Temporary Organization as a fabric of space where the actors and the non-actors are related through a network. Irrespective of the spatial considerations where the actors may be located anywhere in the network, or even independent of their social unit (such as a group or permanent organization) to which the actors may belong to, it is possible to explain the nature and quality of the interactions between the actors and the actors and non-actors using network of relationships. i.e., Actor-Network Theory (Latour, 1996). Furthermore, ANT clearly explains the interaction between the project actors and project work (in the context of present study, actors and project work acting as entity and event respectively). The actors in temporary organization come together to formulate a 'question' which becomes the raison d'atre for initiating the project. The actors have their own interest and this determines the extent to which they will participate in the network. On the other hand, the project work is represented as the non-human actor. This could include any project artifact such as a milestone, deliverable, or a methodology that directs the project actors' efforts. While the actors and the non-human actors may be a result of a network (such as a temporary organization), the strength of the network is itself defined by how well the project actors are able to comprehend and articulate their own interests to others, positioning them as being indispensable (called problematization), building artifacts within the network (such as the project plans) in which the project actors will fit in (interessement), and getting the project actors to work towards a certain goal (locking and mobilization).

Hence, it can be inferred that the interaction between the human and non- human actors in a temporary organization will lead to certain outcomes. Drawing from this argument, we propose that such interaction between the project actors and the project work will lead to an outcome such as motivation.

Thus, specifically ANT is used to explain the moderating variables that affect the relation between the event (work characteristics), and event outcome (work motivation).

\section{Propositions}

In the previous section, we have proposed that nature of project work (which is an interaction between the project actor and the project structure) leads to motivation. However, given the temporary nature of the project organization where the role of the project actors will vary across the project lifecycle, the project actor's role may moderate the relationship between motivating characteristics of project work, and work motivation.

Morgeson, Mitchell, and Liu (2015) in their Event- System theory (EST) propose that 'event strength' moderates the relationship between event, and the achievement of outcomes. This event strength has three constructs: novelty, criticality, and disruption.

\subsection{Moderating Role of Event Novelty}

Novelty refers to the extent to which an event differs from the past events, or when it is an unexpected phenomenon. Moregson, Mitchell, and Liu (2015) further characterize novelty as events that are uncommon, unacticipated, and non-routine (Bechky, \& Okhuysen, 2011). Taking the argument further, they propose that more novel an event, the more likely it will create behaviors, features, or events.

Translating this to the case of temporary organizations, we propose that more novel the project work , the more likely it is seen as motivating.

We will need to refer back to the ANT in order to conceptualize how the project actors determine the novelty of events in the case of temporary organizations. ANT recognizes not just the co-existence of multiple actors with varied interests but all the actors interacting together to mobilize a network. Rather than the agency of a dominating 
actor, ANT proposes that autonomous actors interact in a negotiation space through which novelty emerges. This interaction of project actors is called interessement. In case of temporary organizations, the quality of interactions become more complex as the project organization may have to interact with traditional hierarchy (if the temporary organization is a part of the larger permanent organization) and conduct cross-functional coordination mechanisms (Clegg, 2012). Conducting cross-functional mechanisms will include the project actors to engage in the network in order to formulate a question or issue-the raison d'atre of project (which according to ANT is called Problematization); engage in on going negotiations/interactions that occur between the human and non-human actors which perceive their own interest to participate in the network -Interessement; and create a variety of project artefacts such as project data as a result of this intereaction- called Translation. However, in case of temporary organizations, the interactions between the project actors may not occur in a predictable -linear fashion, and significant efforts are required to translate or create project artefacts. There is a constant back and forth interaction between the project actors which is essential to build and maintain the temporary organization network. In here, the role of the non human actors, also needs to be underscored in maintaining the temporary organization network. These artefacts such as project information, milestones, deliverables or other such objects help in interfacing, focalizing, and controlling the human actors' interaction. This then suggests that the temporary organization networks are not static, but dynamic where the artefacts are constantly evolving (such as progressive elaboration of project requirements), and the project actors constantly need to engage in learning to be able to continue to build and maintain the temporary organization network.

Support for these arguments can be found in the works of Aramo-Immonen, Koskiken, and Porkka (2011) who posit that project-based companies and projects within such companies should move from a position where they solve problems to where they continuously learn to improve their knowledge and skills under conditions of uncertainty.

Thus, adapting to novel, unprecedented situations through learning becomes an essential cog in the project management wheel. Building on the work of Engeström (2001), they posit that the project work itself acts as a context for learning environment. When the project work requires questioning the existing standard practices, it leads to 'expansive learning', producing new patterns of activity. Such expansive learning is spread across the entire temporary organization, affecting all the actors.

A clear analogy can be drawn to the events-system theory where an event is triggered and spatially disperses across the temporary organization. New forms of work activity, and knowledge sharing become important in acquiring and dispersing such learning. It will require the project actors to consciously engage in learning activities which will move them from an 'as is' state to the 'to be' desired state where they improve their competence (Senge, 1990). Furthermore, the motivation to engage in such learning comes from the arrangement of the project organization itself where the team members know that their skills and knowledge is worthless without links to the other team members (Aramo-Immonen, Koskiken, and Porkka, 2011). From the job design perspective to work motivation, we know that work which is intellectually stimulating, requires application of variety of skills and knowledge, requires application of advanced knowledge is motivating to the employees. In the context of temporary organizations, during the process of translation, the extent to which it requires the project actors to create project artefacts using such motivating job characteristics then will lead to motivation. Thus, we put forward the following proposition:

Proposition 1: The more novel the work characteristics, the more likely it is to affect work motivation.

\subsection{Moderating Role of Event Criticality}

Event criticality refers to the degree to which an event is construed to be a priority, or essential (Morgeson, \& DeRue, 2006). The more critical an event, more likely it is that resources will be expended. The actors will have to consciously determine the criticality of the event, and how much of resources need to be devoted to manage the event.

Using ANT as the theoretical lens, 'problematization' and 'interessement' 'best operationalizes the assessment of Event Criticality. Problemitization refers to the group of actors coming together to define the problem, or set of problems, and define the identities of the actors and their role in the network (Callon, 1986). This phase also includes how the problem affects the other actors in the network. In case of projects, it is usually the project manager who frames the problem in its own terms, identifies the relevant actors, and assesses the impact of the problem on the actors in the network. This phase is also characterized by project actors clearly identifying their areas of interests/ priorities (Loufrani-Fedida \& Missonier, 2015). The degree to which the actors assess the influence of other actors in the network and therefore assess their criticality will depend on the 'centrality' and 'density' of the actor network. These will in other words, determine the organization's response to a stakeholders's demand. Density is the number of relative ties which link the actors in the network. Higher the density of the network, more will be the 
communication between the actors in the network, and higher will be the dispersion of values, norms, and shared expectations between the actors. Centrality refers to the individual actor's position in the network in relation to the others. More central the project actor in the network, the stronger will be her case to direct others to satisfy her interests. The expectations once set, are then reinforced further in the interessement stage where the actors' goals and interests are aligned. Trust, and knowledge is shared between the project actors (Alderman \& Ivory, 2011). Thus, based on this understanding, we propose that higher the percpetions of criticality as perceived by the project actor, greater will be the support from the other project actors, greater will be congruence of goals between the project actors, and therefore, higher will be the work motivation. This can be inferred from the motivating nature of project work where the goals are specific and shared by the project actors, and there is free exchange of communication and information between the project actors. Thus, we put forward proposition 2.

Proposition 2. The more critical the work characteristics, the more likely it is to affect work motivation.

\subsection{Moderating role of Event Disruption}

The discussion on sharing of information between the project actors then leads us to the question on how easily can this information be exchanged between the project actors. While the convergence of goals, values, and other such dispositional variables between the project actors is capable of easing the movement of information across the network, the uniqueness of information, and how different is it from the routine information which the project actors handle. This then leads to the question of understanding how 'disruption' works.

According to the Event-System theory, disruption refers to the discontinuity in routine work (Stigliani, \& Ravasi, 2012). This will require the actors to make changes to the behavior, process more information (related to the consequent event of the disruption), or even create new behaviors, and events. Further, it is proposed that the more disruptive an event, the more likely it is that changes will have to be made to the behaviors or events. The very arrangement of temporary organizations within a permanent organization suggests 'disruption'. For example, an administrative boundary may be created between the temporary project organization and rest of the organization to facilitate division of labor between a project and routine operations, and allocation of resources for achieving its objectives (Elbanna, 2015). It is true even in case of multiple projects, where projects are bundled within Programs, so as to better utilize resources, and achieve common benefits. The boundaries then exist between the programs within the larger permanent organization. This concept has been further elucidated by bringing in the actor-network theory perspective through the creation of negotiation space. It is a bounded space within the organization where the stable network of socio-technical objects are built. This is the space where plans, ideas, designs and other such artefacts related to the project are generated and explored (Callon, 1986). Although there is one view which states that the intereractions (between the project actors to create artefacts) is isolated within the boundary where the interactions occur to create outcomes specific to that project, other points of view call for a broader conceptualization of projects as being multi-disciplinary, having multiple purposes, and being a 'permeable' system (Elbanna, 2015). In either of these cases, it is acknowledged that it requires complex interactions between the human and the non-human actors to construct a workable network.

From the job design perspective to work motivation, we know that the extent of access to information, and interaction between the actors is a determinant of work motivation. Viewing this against the light of ANT, we propose that greater the interaction between the project actors, and greater the access to project related information such as artefacts, less challenging will it be to construct, and maintain the network of relationships. This translates to lesser perception of disruption. Lesser the perception of disruption, higher is the work motivation. Hence, we bring forward the proposition:

Proposition 3. The more disruptive the work characteristics, the more likely it will affect work motivation3.4 Participant Flow

For experimental and quasi-experimental designs, there must be a description of the flow of participants (human, animal, or units such as classrooms or hospital wards) through the study. Present the total number of units recruited into the study and the number of participants assigned to each group. Provide the number of participants who did not complete the experiment or crossed over to other conditions and explain why. Note the number of participants used in the primary analyses. (This number might differ from the number who completed the study because participants might not show up for or complete the final measurement.)

\section{Contribution}


In this paper, we have built an interaction between literature from I/O psychology, open systems theory, and temporary organizations. This approach has potential to provide meaningful insights to all the interacting domains. Specifically, we believe we have made the following contribution to advance the theory:

\subsection{Contribution to Temporary Organization Research}

There is an ongoing dialog in project management research to reconcile the differences between traditional project management practices and temporary organizations (c.f. Bakker, DeFillippi, conceptualized temporary organizations using an emerging systems perspective. While there have been numerous other studies which have conceptualized temporary organizations as a 'system', these theories may not have completely considered the dynamic nature of the temporary organizations. Using an emerging theory such as Event-System theory that takes into account both the static nature of temporary organizations- where the standard routines/processes are conducted, and its dynamic nature- where progressive elaboration of information may require the project actors to 'adjust' managing the temporary organization is a step forward. Furthermore, Burke and Morley (2016) provide a comprehensive review of configurations of different types of temporary organizations (intra-organizational, inter-organizational, project-based organizations, and project-based enterprises/firms).

Conceptualizing temporary organizations using an open-system approach/Event-System theory would serve as a generic framework overarching these different configurations of TOs as each of these different types of temporary organizations can be conceptualized as a System; and the work characteristics can be explained as Events leading to Event outcomes irrespective of the type of TO.

\subsection{Conceptualization of Work Motivation in Temporary Organizations Through Integrating Theories}

The second contribution has been to the theories of work design. Broadly, our paper responds to Locke (2004) call for building on a seamless theory of work motivation.

Reviewing the literature review from the job design perspective to work motivation in temporary organizations gave us a sense of how well the theoretical bases for work motivation have been formalized in this domain. However, the theories are perhaps more relevant to stable permanent organization structures vis-à-vis the dynamic temporary organizations. Furthermore, the contribution of human and non-human actors may be equally important in the nature of temporary organizations. In integrating the job design theories (largely drawn from the 'static' Socio-Technical Systems perspective) with the dynamic event-systems theory (which takes into account the dynamic interaction between the human and the non-human actors in producing outcomes), we have been able to propose a more robust theoretical lens of work motivation applicable to temporary organizations.

\subsection{Application of Actor-Network Theory to Explain Dynamics of Work Motivation in Temporary Organizations}

The third contribution pertains to the use of Actor-Network Theory to explain the moderation effects on the relation between motivating nature of project work and work motivation. One of the limitations of the event-system theory is that it has explained the moderation effects on the relation between event and the outcome in case of permanent organization. The three moderating variables- disruption, novelty, and criticality offer a very generic explanation of how they moderate the relation. Of course, it is the intention of the theory which is perhaps emerging, and its purpose is to offer a general framework which is applicable to any organization system at large. However, our purpose to use Event-Systems theory is more specific. We have considered a specific event- interaction between two entities project actors and project artefacts in bringing about an (event)outcome- work motivation. Actor- Network theory provides us a plausible solution. As opposed to the permanent organization where the role of human and non-human actors is fairly constant and perhaps arranged in a hierarchy, temporary organizations are characterized as a network of temporary arrangements. The human and the non-human actors may be interacting differently with each other at different points of time during the course of the project, and will liaison with other networks within the temporary organization in order to produce the results. Thus, the variables of disruption, novelty, and criticality will also be affected by the interconnections of the human and non-human actors in the network. Thus, their moderation effects will also vary based on these interconnections.

\section{Conclusion}

In this paper, we have attempted to provide a conceptual model to explain work motivation in case of temporary organization. The current theories of work motivation do not adequately consider the dynamic nature of temporary organizations. Furthermore, the theoretical lenses of work motivation may not have been completely formalized in the temporary organizations literature. we make an attempt to address these limitations. While we do not state this to 
be definitive framework to investigate work motivation in temporary organizations, we believe this will start a dialogue among project management academia and practitioners. More specifically, we refer to Zahra and Newey (2009) for potential contribution of this research study. My research design allows us to apply both qualitative and quantitative research techniques to examine the dynamics of work motivation in case of temporary organizations. This predictive ability of my research design coupled with significant explanatory power provided by interacting theories has the potential to advance the theory. To the best of my knowledge, using the systems perspective to explain motivation in temporary organizations context is unique to project management literature. It is however, what we hope is a beginning of a constructive dialog, and a long but exciting journey- a posse ad esse!

\section{References}

Adams, J.S. (1965). Inequity in social exchange. In L. Berkowitz (Ed.), Advances in experimental social psychology. New York: Academic Press.

Alderman, N., \& Ivory, C. (2011). Translation and convergence in projects: An organizational perspective on project success. Project Management Journal, 42, 17-30. https://doi.org/10.1002/pmj.20261

Allport, F, H. (1967). A Theory of Enestruence (Event-Structure Theory): Report of Progress. American Psychologist, 22, 1-24. https://doi.org/10.1037/h0024249

Allport, F.H. (1940). An Event-System Theory of Collective Action: With Illustrations from Economic and Political Phenomena and the Production of War. Journal of Social Psychology, 11, 417-445. https://doi.org/10.1080/00224545.1940.9918762

Andersen J. (2010). An Empirical Study of Design Management Practices in Collaborative design and Construction Projects- The roles, activities, and conceptions of design management across project stages, and within the building. Civil, and Process sectors of a construction company. PhD Thesis-School of Engineering, University of Queensland

Aramo-Immonen, H., Koskinen, K.U., \& Porkka, P.L. (2011). The significance of formal training in project-based companies. International Journal of Managing Projects in Business, 4, 257-273. https://doi.org/10.1108/17538371111120234

Assudani, R., \& Kloppenborg, T. (2010). Managing stakeholders for project management success: An emergent model of stakeholders. Journal of General Management, 35, 67-80. https://doi.org/10.1177/030630701003500305

Badir, Y.F., Buechel, B., \& Tucci, C.L. (2012). A conceptual framework of the impact of NPD project team and leader empowerment on communication and performance: An alliance context. International journal of project management, 30, 914-926. https://doi:10.1016/j.ijproman.2012.01.013

Bandura, A., \& Cervone, D. (1986). Differential engagement of self-reactive influences in cognitive motivation. Organizational Behavior and Human Decision Processes, 38, 92-113; https://doi.org/10.1016/0749-5978(86)90028-2

Bechky, B.A., \& Okhuysen, G.A. (2011). Expecting the Unexpected? How SWAT officers and film crews handle surprises. Academy of Management Journal, 54, 239-261. https://doi.org/10.5465/AMJ.2011.60263060

Björklund, T.A. (2010). Enhancing creative knwoledge-work: challenges and points of leverage. International Journal of Managing Projects in Business, 31, 517-525. https://doi.org/10.1108/17538371011056110

Burke, C.M., \& Morley, M.J. (2016). On temporary organizations: A review, synthesis, and research agenda. Human Relations, 69, 1235-1258. https://doi.org/10.1177/0018726715610809

Callon, M. (1986). The sociology of an actor-network: The case of the electric vehicle. In J.L. Callon \& A. Rip (eds.) Mapping the Dynamics of Science and Technology: Sociology of Science in the real world. London: MacMillan Press

Callon, M. (1987). Society in the making: The study of technology as a tool for sociological analysis. In Bijker, W., Hughes, T., \& Pinch, T. (eds.), The social construction of technological systems, Cambridge: MIT Press.

Campbell, J.P. (1990). Modeling the performance prediction problem in industrial and organizational psychology. In M.D. Dunnette \& L.M. Hough (Eds.), Handbook of Industrial and Organizational Psychology, 1, 687-732. Palo Alto, CA: Consulting Psychologists Press. 
Castells, M. (1996). The Rise of the Network Society: The Information Age: Economy, Society, and Culture. Oxford: Blackwell Publishers.

Champoux, J. (1980). A three sample test of some extensions to the job characteristic model of work motivation. Academy of Management Journal, 23, 466-78. https://doi.org/10.5465/255512

Cherns, A.B. (1976). The principles of Organizational design. Human Relations, 29(8), 783-792. https://doi.org/10.1177/001872677602900806

Clegg, S., \& Courpasson, D. (2004). Political hybrids: Tocquevillean views on project organizations. Journal of Management Studies, 41, 525-547. https://doi.org/10.1111/j.1467-6486.2004.00443.x

Cronbach, L.J. (1957). The Two Disciplines of Scientific Psychology. American Psychologist, 12, 671-684, http://dx.doi.org/10.1037/h0043943

Cicmil, S., \& Hodgson, D. (2006). New possibilities for project management theory: A critical engagement. Project Management Journal, 37(3), 111-122.

Clegg, S. (2012). The End of Bureaucracy?, In T. Diefenbach, \& R.Todnem (eds.), Reinventing Hierarchy and Bureaucracy - from the Bureau to Network Organizations (Research in the Sociology of Organizations, NY: Emerald Group Publishing Limited.

Clegg, S., \& Haugaard, M. (2009). The Sage Handbook of Power. UK: Sage Publications.

Cohen, Y., Ornoy, H., \& Baruch, K. (2013). MBTI personality types of project managers and their success: A field survey. Project Management Journal, 44(3), 78-87. https://doi.org/10.1002/pmj.21338

Csikszentmihalyi, M. (1975). Beyond Boredom and Anxiety. Jossey-Bass, San Francisco, CA.

Deci, E.L., \& Ryan, R.M. (1985). Intrinsic motivation and self-determination in human behavior. New York: Plenum.

Elbanna, S. (2015). Intuition in project management and missing links: Analyzing the predicating effects of environment and the mediating role of reflexivity. International Journal of Project Management, 33, 1236-1248. https://doi.org/10.1016/j.ijproman.2015.02.004

Emery, F.E. (1978). The Emergence of a New Paradigm Work. Canberra: Centre for Continuing Education, A.N.U.

Emery, F.E., \& Emery, M. (1976). A Participative Approach to Democratization of Work Place. Appendix in F.E. Emery, \& E. Thorsud, Democracy at Work, Liden: Martinus, Nijhoff

Engeström, Y. (2001). Expansive learning at work: Toward an activitiy theoretical reconceptualization. Journal of Education and Work, 14(1), 135-156. https://doi.org/10.1080/13639080020028747

Hackman, J.R., \& Lawler, E.E. (1971). Employee reactions to job characteristics. Journal of Applied Psychology Monograph, 55, 259-286, http://dx.doi.org/10.1037/h0031152

Hackman, J.R., \& Oldham, G.R. (1976). Motivation through the design of work:Test of a theory. Organization Behavior and Human Performance, 16, 250-279. https://doi.org/10.1016/0030-5073(76)90016-7

Herzberg, F., Mausner, B., \& Snyderman, B.B. (1959). The Motivation to Work. NY: John Wiley.

Johns, G. (2006). The essential impact of context on organizational behavior. Academy of Management Review, 31, 386-408. https://doi.org/10.2307/20159208

Jean-Louis, D., Langley, A., \& Rouleau, L. (2007). Strategizing in pluralistic contexts: Rethinking theoretical frames. Human Relations, 60(1), 179-215. https://doi.org/10.1177/0018726707075288

Kahneman, D. (2011). Thinking fast and slow, New York: Farrar Straus and Giroux.

Kanfer, R. (1990). Motivation theory and industrial/organizational psychology. In M.D. Dunnette and L. Hough (Eds.), Handbook of industrial and organizational psychology. Vol 1. Theory in industrial and organizational psychology (pp.75-170), Palo Alto, CA: Consulting Psychologists Press.

Kanfer, R. (2009). Work motivation: Advancing theory and impact. Industrial and Organizational Psychology, 2(1), 118-127. https://doi.org/10.1111/j.1754-9434.2008.01120.x

Kanfer, R., Chen, G., \& Pritchard, R. (2008). Work motivation: Past, Present, and Future (SIOP Organizational Frontier Series, 1st Ed.), NY: Routledge.

Karasek, R.A. (1979). Job demands, job decision latitude, and mental strain: Implications for job redesign. 
Administrative Science Quarterly, 24, 285-311. https://doi.org/10.2307/2392498

Katz, D., \& Kahn, R.L. (1998). The Social psychology of Organizations. II Ed., NY: Wiley.

Katzell, R.A., \& Thompson, D.E. (1990). Work motivation: Theory and practice. American Psychologist, 45, 144-153. https://doi.org/10.1037/0003-066X.45.2.144

Keegan, A., Huemann, M., \& Turner, R. (2012). Beyond the line: Exploring the HRM responsibilities of line managers, project managers, and the HRM department in four project-oriented companies in The Netherlands, Austria, the UK, and the USA, UK: Taylor and Francis.

Klein, G.A. (1989). Recognition-primed decisions. In W.B. Rouse (Ed.), Advances in man-machine systems research (vol.5, pp.47-92), Greenwich, CT: JAI Press.

Kluger, A.N., \& DeNisi, A. (1996). The effects of feedback interventions on performance: Historical review, a meta-analysis and a preliminary feedback intervention theory. Psychological Bulletin, 119, 254-284. https://doi.org/10.1037/0033-2909.119.2.254

Latham, G., \& Pinder, C. (2005). Work Motivation theory and research at the dawn of the twenty-first century. Annual Review of Psychology, 56, 485-516. https://doi.org/10.1146/annurev.psych.55.090902.142105

Latour, B. (1996). On actor-network theory. A few clarifications plus more than a few complications. Soziale Welt, $47,369-381$.

Latour, B. (2005). Reassembling the social: An introduction to Actor-Network Theory. New York: Oxford University Press.

Leung, M-Y., Chan, Y.S., \& Dondyu, C. (2011). Structural linear relationships between job stress, burnout, physiolgical stress, and performance of construction project managers. Engineering, Construction and Architectural Management, 18(3), 312-328. https://doi.org/10.1108/09699981111126205

Levitt, R.E. (2012). Editorial: Special Issue on Fundamentals of social and management science for engineering $\begin{array}{lllll}\text { project organizations. } & \text { Engineering }\end{array}$ https://doi.org/10.1080/21573727.2012.651836

Lewin, K. (1951). Field theory in social science. New York: Harper and Row.

Lewin, K., Dembo, T., Festinger, L., \& Sears, P. (1944). Level of aspiration. In J. McV.Hunt (Ed.), Personality and the behavior disorders. Vol.1, NY: Ronald Press.

Li, H., Bingham, J.B., \& Umphress, E.E. (2007). Fairness from the top: Perceived procedural justice and collaborative problem solving in New Product Development.Organization Science, 18, 200-216; http://dx.doi.org/10.1287/orsc.1060.0231

Ling, F.Y., \& Loo, C.M. (2015). Characteristics of jobs and jobholders that affect job satisfaction and work performance of project managers. Journal of Management Engineering, 31(3), 401-403. https://doi.org/10.1061/(ASCE)ME.1943-5479.0000247

Locke, E., \& Latham, G. (2004). What Should We Do About Motivation Theory: Six Recommendations For the Twenty-First Century. Academy of Management Review, 29(3), 388-403.

Loufrani-Fedidaa, S., \& Missonier, S. (2015). The project manager cannot be a hero anymore! Understanding critical competencies in project-based organizations from a multilevel approach. International Journal of Project Management, 1220-1235. https://doi.org/10.1016/j.jproman.2015.02.010

Lundin, R.A., \& Söderholm, A. (1995). A theory of the temporary organization. Scandinavian Journal of Management, 11(4), 437-455. https://doi.org/10.1016/0956-5221(95)00036-U

Magnusson, D., \& Endler, N.S. (Eds.). (1977). Personality at the crossroads: Current issues in interactional psychology. Hillsdale, NJ: Erlbaum.M.

Mahoney, R.C., \& Lederer, A.L. (2006). The effect of intrinsic and extrinsic rewards for developers on information systems project success. Project Management Journal, 37(4), 42-55; https://doi.org/10.1177/875697280603700405

Mattias, J., Lundin, R., \& Söderholm, A. (2014). Researching projects and theorizing families of temporary organizations. In the Proceedings of 30th EGOS Colloquium, Rotterdam, The Netherlands, July 3-5, 2015.

Morgeson, F.P. (2005). The external leadership of self managing teams: Intervening in the context of novel and 
disruptive events. Journal of Applied Psychology, 90, 497-508. https://doi.org/10.1037/0021-9010.90.3.497

Morgeson, F.P., \& DeRue, D.S. (2006). Event criticality, urgency, and duration: Understanding how events disrupt teams and influence team leader intervention. Leadership Quarterly, 17, 271-287; http://dx.doi.org/10.1016/j.leaqua.2006.02.006

Morgeson, F., \& Humphrey, S. (2006). The work design questionnaire (WQQ): Developing and validating a comprehensive measure for assessing job design and the nature of work. Journal of Applied Psychology, 91, 1321-1399. https://doi.org/10.1037/0021-9010.91.6.132

Morgeson, F., Mitchell, T., \& Liu, D. (2015). Event System Theory: An Event Oriented Approach to Organizational Sciences. Academy of Management Review, 40(4), 515-537. https://doi.org/10.5465/amr.2012.0099

Müller, R., \& Turner, R. (2010). Leadership competency profiles of successful project managers. International Journal of Project Management, 28, 437-448. https://doi.org/10.1016/j.ijproman.2009.09.003

Mumford, E. (2006). The story of socio-technical design: reflections on its success, failures, and potential. Information Systems Journal, 16(4), 317-342. https://doi.org/10.1111/j.1365-2575.2006.00221.x

Naylor, J.C., Pritchard, R.D., \& Ilgen, R.D. (1980). A theory of behavior in organizations. New York: Academic Press.

Nesheim, T., \&Smith, J. (2015). Knowledge sharing in projects: Does employment arrangement matter?, Personnel Review, 44(2), 255-269. https://doi.org/10.1108/PR-11-2013-0203

Packendorff, J. (1995). Inquiring into the temporary organization: New directions for project management research. Scandinavian Journal of Management, 11(4), 319-333. https://doi.org/10.1016/0956-5221(95)00018-Q

Parker, S.K., Wall, T.D., \& Cordery, J.L. (2001). Future work design research and practice: Towards an elaborated model of work design. Journal of Occupational and Organizational Psychology, 74, 413-440; https://doi.org/10.1348/096317901167460

Paul, W.J., \& Robertson, K.B. (1970). Job enrichment and employee motivation. London: Gower.

Paul, W.J.Jr., Robertson, K.B., \& Herzberg, F. (1969). Job enrichment pays off. Harvard Business.

Pinder, C. (1998). Work motivation in Organizational Behavior. Upper Saddle River, NJ: Prentice-Hall.

Pinto, J.K., \& Precott, J.E. (1988). Variations in critical success factors over the stages in the project life cycle. Journal of Management, 14(1), 5-18. https://doi.org/10.1177/014920638801400102

Procaccino, J.D., Verner, J.M., \& Lorenzet, S.J. (2006). Defining and Contributing to Software Development Success: Determining the Process-Related Components affecting Software Developers' Perception of Project Success. Communications of the ACM, 49(8), 79-83.

Rockeach, Milton. (1973). The nature of human values. New York: The Free Press.

Rose, T.M., \&Manley, K. (2010). Motivation toward financial incentive goals on construction projects. Journal of Business Research, 64(7), 765-773. https://doi.org/10.1016/j.jbusres.2010.07.003

Rowe, F. (2012). Toward a richer diversity of genres in information systems research: New categorization and guidelines. European Journal of Information Systems, 21(5), 469-478. https://doi.org/10.1057/ejis.2012.38

Ryan, R.M., \& Deci, E.L. (2000). Intrinsic and Extrinsic Motivations: Classic Definitions and New Directions. Contemporary Educational Psychology, 25, 54-67. https://doi.org/10.1006/ceps.1999.1020.

Sage, D., Dainty, A., \& Brookes, N. (2011). How actor-network theories can help in understanding project complexities. International Journal of Managing Projects in Business, 4, 274-293. https://doi.org/10.1108/17538371111120243

Schmid, B., \& Adams, J. (2008). Motivation in project management: The project manager's perspective. Project Management Journal, 39(2), 60-71. https://doi.org/10.1002/pmj.20042

Senge, Peter. (1990). The leader's new work: Building the learning organization. Sloan Management Review, 32, 7-23.

Sieler, S., Lent, B., Pinkowska, M., \& Pinazza, M. (2012). An integrated model of factors influencing project managers' motivation-Findings from a Swiss Survey. International Journal of Project Management, 30(1), 60-72. https://doi.org/10.1016/j.ijproman.2011.03.002 
Skinner, B.F. (1953). Science and human behavior, New York: Macmillan.

Söderlund, J. (2004). Building theories of project management: Past research, questions for the future. International Journal of Project Management, 22, 183-191. https://doi.org/10.1016/S0263-7863(03)00070-X

Stigliani, I., \& Ravasi, D. (2012). Product design: A review and research agenda for management studies. International Journal of Management Reviews, 14, 464-488. https://doi.org/10.1111/j.1468-2370.2012.00330.x

Strathern, M. (1991). Partial Connections. Savage, Maryland: Rowman and Littlefield.

Taylor, F.W. (1911). The principles of scientific management. New York: Harper.

Trist, E., \& Bamforth, W. (1951). Some social and psychological consequences of the long wall method of coal getting. Human Relations, 4, 3-38. https://doi.org/10.1177/001872675100400101

Turner, J., \& Müller, R. (2003). On the nature of the project as a temporary organization. International Journal of Project Management, 21, 1-7. https://doi.org/10.1016/S0263-7863(02)00020-0

Turner, J., Huemann, M., \& Keegan, A. (2008). Human Resource Management in the Project-Oriented Organization. PA, USA: Project Management Institute. https://doi.org/10.1016/j.ijproman.2008.05.005

Turner, R., \& Lloyd-Walker, B. (2008). Emotional Intelligence (EI) capabilities training: Can it develop EI in project teams? International Journal of Managing Projects in Business, 1(4), 512-534, https://doi.org/10.1108/17538370810906237

Walker, C.R., \& Guest, H. (1952). The man on the assembly line. Cambridge, MA: Harvard University Press.

Welch, C., Welch, D., \& Tahvanainen, M. (2008). Managing the HR dimension of international project operations. International Journal of Human Resource Management, 19, 205-222. https://doi.org/10.1080/09585190701799754

Zahra, S.A., \& Newey, L.R. (2009). Maximizing the impact of organization science: Theory building at the intersection of disciplines and/or fields. Journal of Management Studies, 46, 0022-2380. https://doi.org/10.1111/j.1467-6486.2009.00848.x 